\title{
Natural iron enrichment around the Antarctic Peninsula in the Southern Ocean
}

\author{
M. V. Ardelan ${ }^{1,6}$, O. Holm-Hansen ${ }^{2}$, C. D. Hewes ${ }^{2}$, C. S. Reiss ${ }^{3}$, N. S. Silva ${ }^{4}$, H. Dulaiova ${ }^{5}$, E. Steinnes ${ }^{6}$, and \\ E. Sakshaug ${ }^{1}$ \\ ${ }^{1}$ Norwegian University of Science and Technology (NTNU), Department of Biology, Trondheim 7491, Norway \\ ${ }^{2}$ Polar Research Program, Marine Biology Research Division, Scripps Institution of Oceanography, University of \\ California-San Diego, La Jolla, CA 92093-0202, USA \\ ${ }^{3}$ NOAA Fisheries, Antarctic Ecosystem Research Division, La Jolla, CA 92037, USA \\ ${ }^{4}$ Pontificia Universidad Católica de Valparaíso, Escuela de Ciencias del Mar, Chile \\ ${ }^{5}$ Woods Hole Oceanographic Institution, Department of Marine Chemistry and Geochemistry, Woods Hole, MA 02543, USA \\ ${ }^{6}$ Norwegian University of Science and Technology, Department of Chemistry, Trondheim 7491, Norway
}

Received: 21 May 2009 - Published in Biogeosciences Discuss.: 24 July 2009

Revised: 8 December 2009 - Accepted: 9 December 2009 - Published: 5 January 2010

\begin{abstract}
As part of the US-AMLR program in JanuaryFebruary of 2006, 99 stations in the South Shetland IslandsAntarctic Peninsula region were sampled to understand the variability in hydrographic and biological properties related to the abundance and distribution of krill in this area. Concentrations of dissolved iron (DFe) and total acidleachable iron (TaLFe) were measured in the upper $150 \mathrm{~m}$ at 16 of these stations (both coastal and pelagic waters) to better resolve the factors limiting primary production in this area and in downstream waters of the Scotia Sea. The concentrations of DFe and TaLFe in the upper mixed layer (UML) were relatively high in Weddell Sea Shelf Waters $(\sim 0.6 \mathrm{nM}$ and $15 \mathrm{nM}$, respectively) and low in Drake Passage waters $(\sim 0.2 \mathrm{nM}$ and $0.9 \mathrm{nM}$, respectively). In the Bransfield Strait, representing a mixture of waters from the Weddell Sea and the Antarctic Circumpolar Current (ACC), concentrations of DFe were $\sim 0.4 \mathrm{nM}$ and of TaLFe $\sim 1.7 \mathrm{nM}$. The highest concentrations of DFe and TaLFe in the UML were found at shallow coastal stations close to Livingston Island $(\sim 1.6 \mathrm{nM}$ and $100 \mathrm{nM}$, respectively). The ratio of TaLFe:DFe varied with the distance to land: $\sim 45$ at the shallow coastal stations, $\sim 15$ in the high-salinity waters of Bransfield Strait, and $\sim 4$ in ACC waters. Concentrations of DFe increased slightly with depth in the water column, while that of TaLFe did not show any consistent trend with depth. Our Fe data are discussed in regard to the hydrography
\end{abstract}

Correspondence to: M. V. Ardelan (murato@nt.ntnu.no) and water circulation patterns in the study area, and with the hypothesis that the relatively high rates of primary production in the central regions of the Scotia Sea are partially sustained by natural iron enrichment resulting from a northeasterly flow of iron-rich coastal waters originating in the South Shetland Islands-Antarctic Peninsula region.

\section{Introduction}

Pelagic waters of the Southern Ocean generally have low chlorophyll- $a$ (chl- $a$ ) concentrations, although some regions such as the Kerguelen Plateau, Crozet plateau, Ross Sea, and Scotia Sea have significantly higher chl- $a$ concentrations (Sullivan et al., 1993; Holm-Hansen et al., 2004; Blain et al., 2007; Pollard et al., 2007). There is ample evidence that the low chl- $a$ concentrations in the pelagic waters of the Southern Ocean are the result of biomass-limiting concentrations of Fe (Martin et al., 1990; Boyd and Law, 2001; Öztürk et al., 2004; Hopkinson et al., 2007; Boyd et al., 2007). Conversely, elevated chl- $a$ concentrations in coastal and plateau areas are thought be the result of re-suspension of iron-rich sediments, iron diffusion from sediment and subsequent upwelling (Korb et al., 2008; Blain et al., 2007,2008; Planquette et al., 2007; Pollard et al., 2007; Hewes et al., 2009). De Baar et al. (1995) have attributed the high chl- $a$ waters in the polar frontal region at $\sim 6^{\circ} \mathrm{W}$ to upwelling of $\mathrm{Fe}$-enriched upper circumpolar deep water into surface waters resulting from the dynamic polar jet. Much of the Scotia Sea, however, is deep and distant from the North and South

Published by Copernicus Publications on behalf of the European Geosciences Union. 
Scotia Ridges as well as the shelf regions surrounding South Georgia and the South Sandwich Islands. Yet chl- $a$ concentrations are relatively high $\left(>1.0 \mathrm{mg} \mathrm{m}^{-3}\right.$; Fig. 1a).

One possibility for the enrichment of the central portion of the Scotia Sea is Fe fertilization from the continental shelves of the South Shetland Islands (SSI) and the Antarctic Peninsula area (Hoppema et al., 2003), as waters from these areas flow in a northeasterly direction toward South Georgia (Hofmann et al., 1996, 1998). Previous studies (Hopkinson et al., 2007; Hewes et al., 2008) have shown that dissolved $\mathrm{Fe}(\mathrm{DFe})$ concentrations in the South Shetland Islands area (see Fig. 1b) are high $(>1 \mathrm{nM})$, in contrast to the low $\mathrm{Fe}$ values in the Antarctic Circumpolar Current (ACC) waters $(<0.50 \mathrm{nM})$ (Martin et al., 1990; Löscher et al., 1997; Hewes et al., 2008). If enrichment of $\mathrm{Fe}$ is the major factor promoting the high chl- $a$ biomass in the central Scotia Sea, it is important to determine $\mathrm{Fe}$ concentrations in the source waters that flow into this region.

The South Shetland Islands-Antarctic Peninsula region is one of the sites where landmasses strongly interact with Antarctic currents. If enrichment of $\mathrm{Fe}$ from shelf-derived sediments is the major factor promoting the high chl- $a$ concentrations in the central Scotia Sea, this region could be a significant source. In this paper we provide data on concentrations of both dissolved (DFe) and total acid leachable $\mathrm{Fe}(\mathrm{TaLFe})$ at 16 stations that are located in both coastal and offshore regions of the South Shetland Islands area (see Fig. 1b). These data are discussed in regard to phytoplankton $\mathrm{Fe}$ requirements, ratios of dissolved to particulate $\mathrm{Fe}$, and the possible significance of a natural $\mathrm{Fe}$ fertilization from the northern Antarctic Peninsula region for the productivity of the Scotia Sea.

\section{Materials and methods}

\subsection{Field sampling and oceanographic measurements}

All water sampling was done during the Antarctic Marine Living Resources Program (AMLR) aboard the $R / V$ Yuzhmorgeologiya during the period 16 January to 8 February, 2006, in the region of the Antarctic Peninsula and South Shetland Islands (see Fig. 1). The sampling grid consisted of 99 routine CTD (Conductivity-Temperature-Depth) casts to $750 \mathrm{~m}$ (or to within $10 \mathrm{~m}$ of the bottom at shallower stations). The CTD carousel held ten 8-liter General Oceanics Niskin bottles and the following sensors (a) a Chelsea profiling fluorometer for measurement of in situ chl- $a$ fluorescence, (b) a Wet Labs profiling transmissometer for measurement of the attenuation of light at $660 \mathrm{~nm}$, and (c) a cosine PAR (Photosynthetic Available Radiation, 400-700 nm). Continuous profile data were obtained on the down casts. Water samples for chl- $a$ and macronutrient determinations were obtained from the Niskin bottles which were closed on the up casts at $200,100,75,50,40,30,20,15,10$, and $5 \mathrm{~m}$
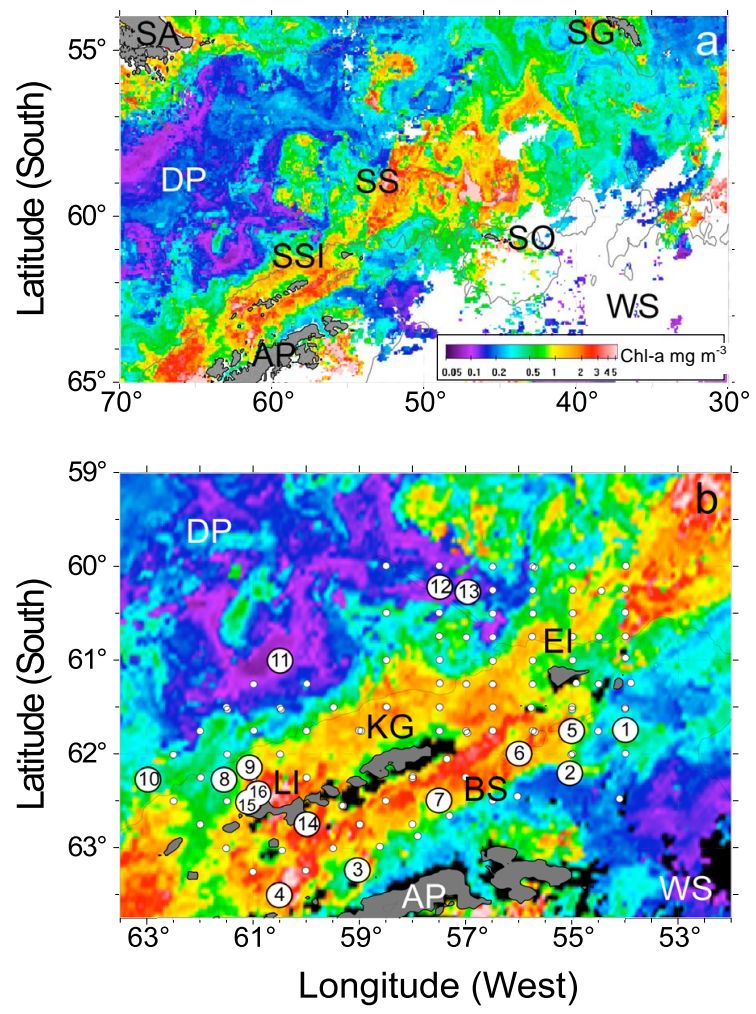

Fig. 1. Satellite images showing mean chlorophyll- $a$ concentrations $\left(\mathrm{mg} \mathrm{m}^{-3}\right)$ of surface waters in the Drake Passage-Scotia Sea regions of the Southern Ocean during January, 2006. The color bar in the top image applies to both images. (a) Large scale map showing high chlorophyll- $a$ concentrations in the central Scotia Sea downstream of the South Shetland Islands region. (b) Antarctic Peninsula region, with the numbered white circles showing location of stations where Fe concentrations were determined. Numbers refer to the stations listed in Table 2 that also provides hydrographic and biological data. The small white circles show the locations of all the stations in the AMLR sampling grid. The thin continuous line in (a) and (b) is the $1000 \mathrm{~m}$ depth isobath. AP, Antarctic Peninsula; DP, Drake Passage; EI, Elephant Island; KG, King George Island; LI, Livingston Island; SA, South America; SO, South Orkney Islands; SS, Scotia Sea; SG, South Georgia; SSI, South Shetland Islands; WS, Weddell Sea. White areas indicate no data due to cloud or ice conditions.

target depths. Water samples for determination of Fe concentrations were obtained as described in Sect. 2.6.

\subsection{Drifter buoy tracks}

Eighteen Langrangean Drifter Buoys were released during the last week of January to examine surface currents at various locations within the AMLR survey area. Based on results from releases during previous years, three general areas of interest were examined: (a) seven drifters were released close to Elephant Island along the northeast and southeast coasts, (b) four drifters were released in the Bransfield Strait south 
and west of Elephant Island, and (c) seven drifters were released to the southeast of King George Island. The locations of these buoys, which had a drogue depth of approximately $15 \mathrm{~m}$, were transmitted daily via orbiting polar satellites.

Data quality control and interpolation to 6-h positions are conducted by the GDP (Hansen and Poulain, 1996).

Additionally, 6-h drifter positions for all drifters released as part of the Global Drifter Program (GDP) were extracted from the Global drifter database (http://www.aoml.noaa.gov/ envids/gld/). We plotted the positions of all drifters that entered the sampling area between 1979 and present to provide a picture of the surface flow, areas of advection off the shelf and areas of re-circulation that could increase the residence time and mixing of different waters in the area.

\subsection{Upper mixed layer depth determination}

Depth of the upper mixed layer (UML) was calculated as the depth at which potential density (sigma-theta) differed by $0.05 \mathrm{~kg} \mathrm{~m}^{-3}$ from the mean potential density measured between 5 and $10 \mathrm{~m}$ depth.

\section{4 chlorophyll- $a$ determination}

chl- $a$ concentrations $\left(\mathrm{mg} \mathrm{m}^{-3}\right)$ were determined by measurement of chl- $a$ fluorescence after extraction in methanol. Sample volumes of $100 \mathrm{ml}$ were filtered through glass fiber filters (Whatmann GFF, $25 \mathrm{~mm}$ ) at a differential pressure of $<1 / 3 \mathrm{rd}$ atmosphere. The filters with the particulate material were placed in $10 \mathrm{ml}$ of absolute methanol in $15-\mathrm{ml}$ tubes and the photosynthetic pigments extracted at $4{ }^{\circ} \mathrm{C}$ for at least $12 \mathrm{~h}$. The samples were then shaken, centrifuged, and the clear supernatant poured into cuvettes $(13 \times 100 \mathrm{~mm})$ for measurement of chl- $a$ fluorescence before and after the addition of 2 drops of $1.0 \mathrm{~N} \mathrm{HCl}$ (Holm-Hansen and Riemann, 1978). Fluorescence was measured using a fluorometer (Turner Designs model 700) that had been calibrated using a prepared chl- $a$ standard (Sigma C-6144) with the concentration determined by spectrophotometry (Jeffrey and Humphrey, 1975). Stability of the fluorometer was verified daily by use of a solid-state fluorescence standard (Turner Designs No. 7000-994).

\subsection{Macronutrient determination}

Water samples $(\sim 50 \mathrm{ml})$ for macronutrient analysis were poured directly from the Niskin sampling bottle on the carousel into acid cleaned $(1 \mathrm{~N} \mathrm{HCl})$ polyethylene bottles of $60 \mathrm{ml}$ capacity. The samples were maintained at $-20^{\circ} \mathrm{C}$ until analysis. An autoanalyzer (Technicon) was used for determination of nitrate+nitrite, phosphate, and silicic acid as described by Atlas et al. (1971). Throughout this paper we refer to the concentration of nitrate + nitrite as nitrate concentration.

\subsection{DFe and TaLFe sampling and determination}

Water samples were collected with acid-cleaned Teflon-lined GO-FLO bottles deployed on trace metal clean polymer $1 / 4^{\prime \prime}$ Sta-Set $\mathrm{X}$ linen (New England ropes) line using a dedicated winch. The samples were taken from depths ranging from 10 to $175 \mathrm{~m}$ to represent the upper mixed layer (UML) and water below the pycnocline. Samples from the GO-FLO bottles were drained into acid-cleaned, 0.5 and 1.0 liter low-density polyethylene (Nalgene) bottles. These bottles were taken to a clean room, placed on a rack under clean air blowing from a Class-100 laminar flow hood and processing of the samples started immediately. Water samples for TaLFe determination were pumped directly into the polyethylene bottles without filtration. For DFe analysis water was driven by peristaltic pump, using acid-washed Tygon tubes, through acid-washed Sartorius filters $(0.4 \mu \mathrm{m}$ pore size filtration followed by $0.2 \mu \mathrm{m}$ pore size filtration).The $\mathrm{DFe}$ fractions were defined operationally by the $0.2 \mu \mathrm{m}$ nominal pore size, and therefore include colloidal Fe During filtration an additional HEPA air-filter cartridge (HEPA-CAP/HEPA VENT, $75 \mathrm{~mm}$, Whatman) was connected to the pressurerelief/air-vent valve of the GO-FLO bottles in order to ensure that the air in contact with the sample during the filtration was clean. All samples for DFe and TalFe were acidified to $\mathrm{pH} 1.7-1.8$ with $15.4 \mathrm{M}$ ultra-pure $\mathrm{HNO}_{3}$ (optima grade, Sigma). The acidified water samples were returned to NTNU and stored for about 7-8 months before analysis.

Pre-concentration of DFe and TaLFe from seawater was carried out by a modified combination of Chelex-100 $\mathrm{Naa}^{+}$ form, 100-200 mesh size, Bio-Rad) batch (Baffi and Cardinale, 1990; Grotti et al., 2001) and column technique (Öztürk, 1995, 2002). Before the Chelex treatment, $\sim 500 \mathrm{ml}$ of the acidified samples were microwaved for $2.5 \mathrm{~min}$ at $1100 \mathrm{~W}\left(\sim 60^{\circ} \mathrm{C}\right)$, allowed to cool for $30 \mathrm{~min}$, and then microwaved again for $2.5 \mathrm{~min}$ in order to break down the remaining strong ligand-Fe complexes and colloidal iron. This is necessary to convert the strong ligand-iron complexes that might not be Chelex-100 labile into labile forms (Bruland and Rue, 2001, 2005). The $\mathrm{pH}$ of the acidified and microwaved samples was brought to $5.7-5.9$ by addition of $1.4 \mathrm{M}$ ultra-pure ammonium acetate buffer immediately before addition of the Chelex-100 slurry as described below. Clean ammonium acetate buffer $(1.4 \mathrm{M})$ was prepared by dilution of isothermally distilled ammonium solution with Milli Q water and slowly mixing with acetic acid (double distilled ultra pure, PPB/Teflon grade, Aldrich) under a fume hood.

Chelex-100 resin was carefully cleaned by repetitive washes with $3 \mathrm{M}$ ultra-pure $\mathrm{HCl}$ (isothermally distilled), $2 \mathrm{M}$ ultra-pure $\mathrm{HNO}_{3}$ (optima grade, Sigma), and Milli Q water $(18.4 \mathrm{~m} \Omega)$ and then converted to $\mathrm{NH}_{4}{ }^{+}$by using isothermally distilled $\mathrm{NH}_{4} \mathrm{OH}$ (see Öztürk et al., 2002, for details of preparation and cleaning the Chelex-100). An aliquot $(0.8 \mathrm{ml})$ of the Chelex-100 slurry $(0.35-0.45 \mathrm{~g}$ dry weight of 
Table 1. Accuracy and precision of the method by using the certified standard materials NASS-5 (National Research Council Canada) and spiked seawater samples. Method and resin blanks with procedural detection limits have been presented in the lower section of the table. The numbers in the parentheses are the number of spikes and blanks.

\begin{tabular}{|c|c|c|c|c|c|}
\hline & & $\begin{array}{l}\text { added } \\
(\mathrm{nM})\end{array}$ & $\begin{array}{l}\text { found } \\
(\mathrm{nM})\end{array}$ & $\begin{array}{l}\% \\
\text { recovery }\end{array}$ & $\%$ rsd \\
\hline Open Ocean Seawater treated with Chelex-100* & Spikes A & & & & \\
\hline (6) & & 0.50 & $0.49 \pm 0.04$ & 98.0 & 8.3 \\
\hline (6) & & 1.0 & $0.97 \pm 0.07$ & 96.7 & 7.5 \\
\hline (6) & & 1.5 & $1.38 \pm 0.17$ & 92.1 & 12.6 \\
\hline (4) & & 18 & $18.3 \pm 1.1$ & 101.7 & 5.8 \\
\hline UVc+Chelex-100 treated seawater $(3)^{*}$ & Spikes B & $2 \mathrm{nM}$ & $1.97 \pm 0.2$ & 99 & 4.0 \\
\hline Coastal SW treated with Chelex-100 (4)* & Spikes C & $20 \mathrm{nM}$ & $16.1 \pm 0.81$ & 83 & 4.1 \\
\hline Coastal SW treated with Chelex-100-microwaved (5)* & Spikes D & $20 \mathrm{nM}$ & $20.88 \pm 0.57$ & 104 & 2.8 \\
\hline NASS 5 (3) & $3.70 \mathrm{nM}$ & & $3.10 \pm 0.33$ & 84 & 7.2 \\
\hline NASS 5 +microwaved (3) & $3.70 \mathrm{nM}$ & & $3.55 \pm 0.4$ & 96 & 4.3 \\
\hline Chelex-100 Blank (8) & & & $0.03 \pm 0.01 \mathrm{nmol}$ & & \\
\hline Method blank (15)** & & & $0.05 \pm 0.02 \mathrm{nmol}$ & & \\
\hline $\begin{array}{l}\text { Procedural detection limits } \\
\text { (with pre-concentration factor 100) }\end{array}$ & & & $0.03 \mathrm{nM}$ & & \\
\hline
\end{tabular}

* Filtered seawater (from station 11 (A1505)) at pH 5.8 treated with Chelex-100 to remove all Chelex labile Fe. and spiked seawater were again treated with Chelex-100 immediately after the addition of iron, Spike C and D were treated with Chelex-100 $24 \mathrm{~h}$ after addition of iron, allowing the added iron to reach the equilibrium with existing natural organic ligands.

** Method blanks: $30 \mathrm{ml}$ Milli-Q water $+10 \mathrm{ml}$ ammonium acetate solution treated exactly as sample with $0.5 \mathrm{~g}$ clean Chelex-100 and eluted similarly.

resin) was added to $500 \mathrm{ml}$ of seawater that had been buffered with ultra-pure ammonium acetate buffer solution to $\mathrm{pH}$ 5.75.9, which is the optimal $\mathrm{pH}$ range for iron pre-concentration on Chelex-100. The samples with Chelex-100 were shaken at $70 \mathrm{rpm}$ for $48 \mathrm{~h}$ at room temperature. All sample treatments and pre-concentration were done in a Class-100 clean laboratory at the Dept of Chemistry at NTNU.

The samples with Chelex-100 were transferred to an acidcleaned plastic Bio-Rad column system pre-loaded with $\sim 0.1 \mathrm{~g}$ clean Chelex-100 resin and allowed to run at a rate of $\sim 2 \mathrm{ml} \mathrm{min}^{-1}$. When this step was completed, the Chelex100 in the column was washed with $20 \mathrm{ml}$ of Milli-Q water and $10 \mathrm{ml} 0.1 \mathrm{M}$ ultra-pure ammonium acetate buffer solution to remove the residue of seawater matrix. For extraction of iron from Chelex-100, $1.0 \mathrm{ml}$ of $2 \mathrm{M}$ ultra-pure $\mathrm{HNO}_{3}$ was added to the column and allowed to react for $10 \mathrm{~min}$, after which the column was gently shaken in order to maximize the contact between the Chelex-100 resin and the $\mathrm{HNO}_{3}$. One $\mathrm{ml}$ of the $\mathrm{HNO}_{3}$ extract in the column was then carefully transferred into an acid-washed $10 \mathrm{ml}$ polyethylene (PE) tube. The same procedure was repeated with $4 \mathrm{ml}$ of $0.25 \mathrm{M}$ ultra-pure $\mathrm{HNO}_{3}$ added to the column. After $30 \mathrm{~min}$, this extract was added to the PE tube containing the first extract. The final volume, $5.0 \mathrm{ml}$ represents a pre-concentration factor of 100 .

DFe and TaLFe were measured using a High Resolution Inductive Coupled Plasma Mass Spectrometer (HR-ICP-MS) Element 2 (Thermo-Finnigan) with PFA-Schott type spray chamber and nebulizer. Plasma and mass spectrometer parameters were optimized daily at a medium resolution of $r$ : 4000. Mass window was $100 \%$. The nebulizer gas flow optimization was done daily. Flushing the sampler tube and sample loop was done with $0.6 \mathrm{M}$ ultra-pure $\mathrm{HNO}_{3}$. The sample uptake rate to plasma was $0.25 \mathrm{~mL} \mathrm{~min}^{-1}$ with a sample/peak ratio of 20. Each analysis used $0.8 \mathrm{ml}$ sample and $1.2 \mathrm{ml}$ washing acid. As the washing and sample scanning times took $30 \mathrm{~s}$, the total time required for three scans of each sample was $90 \mathrm{~s}$. In order to lower the instrumental Fe blank values, $0.6 \mathrm{M}$ ultra-pure $\mathrm{HNO}_{3}$ was run before sample measurements. Element 2 software was used for the analysis.

\subsection{Calibration and performance of iron determination}

Accuracy and precision of the iron determination method were checked using the certified standard materials NASS5 (National Research Council of Canada). Recovery tests were also carried out with seawater spiked with various $\mathrm{Fe}$ additions, showing good recovery for added iron (accuracy and precision are summarized in Table 1). The data reported in this paper represent total concentrations of dissolved iron and the acid-leachable $(\mathrm{pH} \leq 1.8)$ fraction of the total iron. It does not include iron from iron-containing particulate material that is acid-refractory. From an ecological point of view this is not a serious consideration because iron in acid-refractory particles is most likely not available to microbial cells. Comparison between spiked seawater 
Table 2. Data for the 16 stations shown in Fig. $1 \mathrm{~b}$ where concentrations of dissolved and total acid leachable Fe were determined. The five groupings of the stations are based on common characteristics, including water depth and proximity to different water masses such as Weddell Sea water and Drake Passage water. Depth of the upper mixed layer (UML) was calculated as the depth at which sigma-theta differed by $0.05 \mathrm{~kg} \mathrm{~m}^{-3}$ from the mean density between 5 and $10 \mathrm{~m}$ depth. Values shown for temperature, salinity, and chl- $a$ are mean values in the UML.

\begin{tabular}{|c|c|c|c|c|c|c|c|c|c|}
\hline Group & $\begin{array}{c}\text { Station } \\
\text { No. }\end{array}$ & Station ID & $\begin{array}{l}\text { Latitude, } \\
{ }^{\circ} \mathrm{S}\end{array}$ & $\begin{array}{l}\text { Longitude, } \\
{ }^{\circ} \mathrm{W}\end{array}$ & $\begin{array}{c}\text { Bottom } \\
\text { Depth, m }\end{array}$ & $\begin{array}{c}\text { UML } \\
\text { Depth, m }\end{array}$ & Temp., ${ }^{\circ} \mathrm{C}$ & Salinity & $\begin{array}{l}\text { Chl-a, } \\
\mathrm{mg} \mathrm{m}^{-3}\end{array}$ \\
\hline \multirow{4}{*}{ A } & 1 & A0208 & 61.7 & 54.0 & 328 & 141 & 0.44 & 34.35 & 0.83 \\
\hline & 2 & A0410 & 62.2 & 55.0 & 540 & 44 & -0.41 & 34.28 & 0.80 \\
\hline & 3 & A1214 & 63.2 & 59.0 & 147 & 112 & 0.35 & 34.39 & 1.18 \\
\hline & 4 & A1515 & 63.5 & 60.5 & 544 & 20 & 0.92 & 34.30 & 0.99 \\
\hline \multirow{3}{*}{ B } & 5 & A0408 & 61.8 & 55.0 & 2012 & 45 & 1.85 & 34.25 & 1.13 \\
\hline & 6 & A0609 & 62.0 & 56.0 & 2150 & 39 & 2.16 & 34.27 & 1.40 \\
\hline & 7 & A0911 & 62.5 & 57.5 & 1485 & 27 & 2.92 & 34.29 & 1.88 \\
\hline \multirow{2}{*}{ C } & 8 & Y2A1 & 62.3 & 61.5 & 1200 & 45 & 2.75 & 34.04 & 3.97 \\
\hline & 9 & Y8A1 & 62.1 & 61.1 & 1070 & 21 & 2.97 & 33.94 & 2.90 \\
\hline \multirow{4}{*}{ D } & 10 & A2010 & 62.3 & 63.0 & 4078 & 14 & 3.46 & 33.64 & 1.04 \\
\hline & 11 & A1505 & 61.0 & 60.5 & 3708 & 20 & 3.62 & 33.80 & 0.10 \\
\hline & 12 & A0902 & 60.2 & 57.5 & 3284 & 19 & 3.57 & 33.80 & 0.14 \\
\hline & 13 & A0802 & 60.3 & 57.0 & 4079 & 41 & 3.66 & 33.83 & 0.69 \\
\hline \multirow{3}{*}{$E$} & 14 & A1412 & 62.7 & 60.0 & 913 & 24 & 2.28 & 33.97 & 3.66 \\
\hline & 15 & Y2A5 & 62.5 & 61.1 & 335 & 29 & 2.11 & 34.11 & 3.00 \\
\hline & 16 & Y5A5 & 62.4 & 60.9 & 90 & 30 & 1.77 & 34.15 & 2.10 \\
\hline
\end{tabular}

samples with and without microwave treatment revealed that microwaving of the acidified samples managed to quantitatively liberate the Fe from iron-organic complexes stronger than those between iron and the iminodiacetate functional group of Chelex-100. These results indicate that all DFe was quantitatively pre-concentrated by Chelex-100.

\section{Results}

\subsection{Iron concentrations in the upper water column}

Data for the 16 stations shown in Fig. 1b are listed in Table 2. The stations have been divided into five groups (A to E). The stations located in the southern portion of Bransfield Strait (group A, stations 1-4) were the coldest, most saline, and had relatively low chl- $a$ concentrations. Group B stations (5-7), which were in deep waters of Bransfield Strait but close to the shelf break, had higher chl- $a$ concentrations of $>1.0 \mathrm{mg} \mathrm{m}^{-3}$. The deep offshore stations (group D, stations 10-13) have the highest surface temperatures, lowest salinity values, and lowest chl- $a$ concentrations. Highest chl$a$ concentrations were recorded at the three inshore stations of group E (stations 14-16) and the two stations in the inshore survey, which were in deep water, but very close to the shelf break (group C, stations 8 and 9). The water column characteristics of these 16 stations, which are shown in the Temperature/Salinity diagrams in Fig. 2, show that the stations within each of these five groups are quite similar to each other, but that each group is quite distinct from the other four groups.

When the Fe concentrations from all sampling depths at the 16 stations are plotted against the water density, it can be seen that the highest concentrations of both DFe and TaLFe are found in waters with high sigma-theta values, and that the lowest Fe concentrations are found in low-density waters of Drake Passage (Fig. 3). The stations with the highest concentrations of DFe and TaLFe, were the near-shore stations 14-16 (group E), which differed in terms of the iron concentration vs. water density from the other stations (enclosed by circles in Fig. 3a, b). With exception of the inshore data, the TaLFe/DFe ratio varied from $\sim 4$ in low salinity waters to $\sim 15$ in high salinity waters. The ratio for the three inshore stations (group E) ranged from $\sim 12$ to 63 , with a mean of 45 .

Profiles of DFe and TaLFe concentrations with depth ( 0 to $200 \mathrm{~m}$ ) for all stations in each of the five groups are shown in Fig. 4, together with profiles of water density (0 to $400 \mathrm{~m}$ ). At all these stations DFe concentrations were lowest in or slightly below the UML depth, with concentrations increasing at greater depths. Concentrations of TaLFe did not display any consistent pattern with depth.

When the averages for temperature, chl- $a$, nitrate, phosphate, DFe, and TaLFe in the UML at the 16 stations are plotted against salinity (Fig. 5), the data for individual stations within each group (see Table 2) are fairly close together, with each grouping generally separated from the other four 

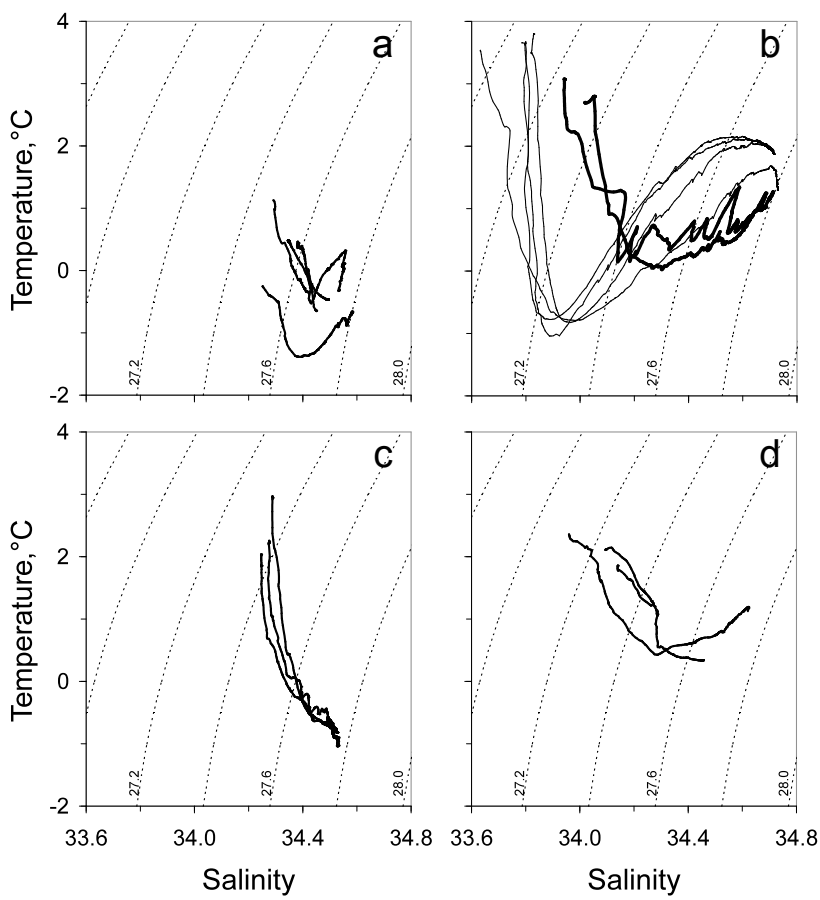

Fig. 2. Temperature/Salinity diagrams for the 16 stations where water samples were obtained for determination of $\mathrm{Fe}$ concentrations. Note that CTD profiles were obtained from the surface to $750 \mathrm{~m}$, or to within $\sim 10 \mathrm{~m}$ of the bottom at the shallower stations (bottom depths are given in Table 2). For station locations, see Fig. 1b. (a), group A stations (\#1 to 4); (b), group D stations (\#10-13) with light lines, and group C Stations (\#8-9) with dark lines; (c), group B stations (\#5-7); (d), group E stations (\#14-16). The thin dotted lines show isopycnal intervals (sigma-q) in temperature/salinity space.

groups. The stations in group A (southern part of the Bransfield Strait) had the lowest temperature (Fig. 5a), low chl- $a$ values (Fig. 5b), highest nitrate and phosphate concentrations (Fig. 5c, d) and highest DFe and TaLFe concentrations (except for the three shallow stations of group E; Fig. 5e, f). The Drake Passage stations (group D) exhibited the highest temperature and the lowest concentrations of chl- $a$, macronutrient, DFe, and TaLFe. Again group E was different, with the highest concentrations of both $\mathrm{DFe}(>1.0 \mathrm{nM})$ and $\mathrm{TaLFe}(>2.0 \mathrm{nM})$ in combination with high chl- $a$ concentration $\left(>2.0 \mathrm{mg} \mathrm{m}^{-3}\right)$. chl- $a$ concentrations exhibited a unimodal relationship with salinity with the maximum concentrations $\sim 34$ (Fig. 5b).

From the data in Figs. 3 and 5 it is seen that stations in group $\mathrm{E}$ had the highest $\mathrm{DFe}$ and TaLFe concentrations but the salinity values at these stations were low $(\sim 34.1)$ as compared to the average salinity of $\sim 34.3$ for stations in group A. As these were relatively shallow coastal stations, it is likely that the high $\mathrm{Fe}$ values were due to runoff from the land or release of $\mathrm{Fe}$ during re-suspension of bottom sediments. Evidence for re-suspension of bottom sediments influencing $\mathrm{Fe}$ concentrations was found from profiles of in situ chl- $a$ flu- orescence and light attenuation at six stations in the coastal survey - the three outermost stations and the three closest to shore (Fig. 6). All six stations had high in situ chl- $a$ fluorescence in the upper $50 \mathrm{~m}$ but no detectable in situ chl- $a$ fluorescence below $200 \mathrm{~m}$. The transmissometer data, however, showed that at the three outermost stations the beam attenuation values decreased rapidly between 50 to $100 \mathrm{~m}$, remained low from 100 to $200 \mathrm{~m}$, and then decreased to very low and constant values down to $350 \mathrm{~m}$ depth. In contrast, the beam attenuation values for the three stations close to shore remained high between 100 and $300 \mathrm{~m}$ depth. Data in Holm-Hansen and Hewes (2004) show profiles of various sensor and other data of 14-years of study in the AMLR survey area. This includes transmissometer data, which on average, is high in the upper $100 \mathrm{~m}$ and generally decays to background values by $200 \mathrm{~m}$, and corresponds with both fluorometric voltages and $\mathrm{Chl}$ concentrations. These patterns were generally observed during the AMLR survey of 2006. For all stations in Fig. 6, chl fluorescence negatively corresponded with transmission volts in the upper $50-100 \mathrm{~m}$, indicating that light attenuation was correlated with chl- $a$ concentration. It was only below $100-200 \mathrm{~m}$ that there was not a correspondence between near shore and off shore profiles of transmissometer and fluorometer voltages. The probability that change in the electronic signal occurred just for the three shallow stations and only below $100-200 \mathrm{~m}$ is extremely unlikely. As this high attenuation of light deep in the water column at the three near shore stations between 100 and $300 \mathrm{~m}$ depth can not be attributed to chl- $a$ absorption, it is most likely to have been caused by re-suspended particulate material from bottom sediments.

\subsection{Co-variation between DFe and TaLFe concentra- tions}

Concentrations of TaLFe, which include Fe from the particulate fraction, increase more rapidly than concentrations of DFe with increasing water density (Fig. 3). The relationship between these two phases of Fe is shown in Fig. 7. Concentrations of DFe tended to level off at $\sim 1.5 \mathrm{nM}$. The ratios of TaLFe/DFe decrease from $\sim 60$ in shallow waters $(90 \mathrm{~m})$ close to shore to $\sim 9.4$ in deep water $(1200 \mathrm{~m}) 50 \mathrm{~km}$ from shore (Fig. 8).

\subsection{Co-variation between $\mathrm{Fe}$ and macro-nutrients}

Concentrations of DFe and nitrate (Fig. 9a) and phosphate (Fig. 9b) covaried. The change in concentrations of nitrate and phosphate relative to that of DFe, however, differed between stations in Bransfield Strait (dark symbols in Fig. 9) where concentrations of DFe are relatively high as compared to the off shore stations (open symbols in Fig. 9) where DFe concentrations are generally low. 

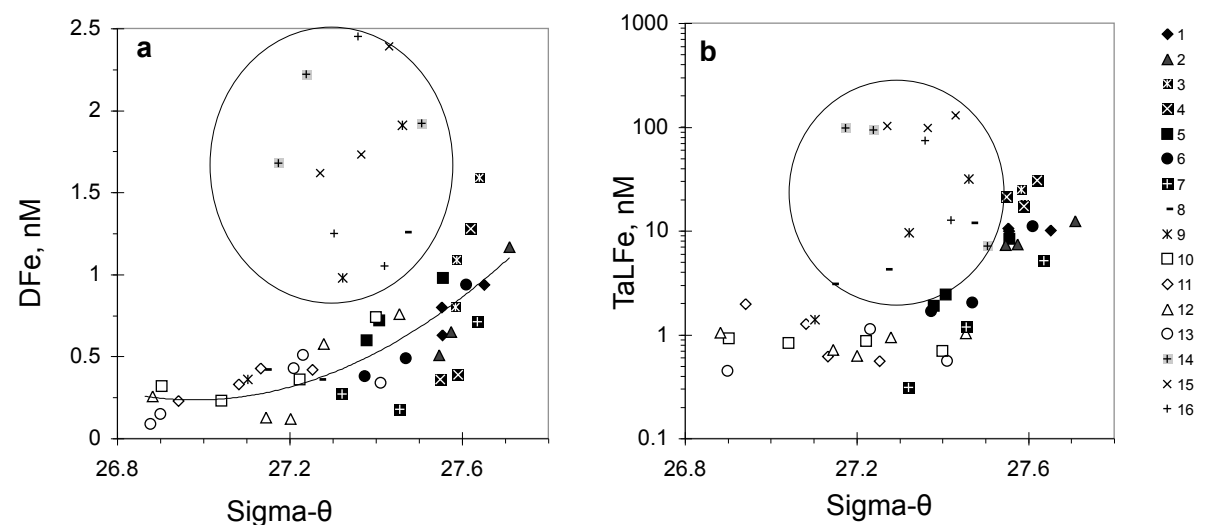

Fig. 3. Fe concentrations in relation to water density. (a) Dissolved Fe (DFe); (b) total acid leachable Fe (TaLFe). Open symbols are from Drake Passage waters. Closed symbols are from station close to or over the continental shelf. Note the change to a log scale ordinate for TaLFe. The stations within the circles are from the near-shore coastal survey (stations $8,9,15,16$ ) and station 14 . Station numbers are shown in the column to the right.
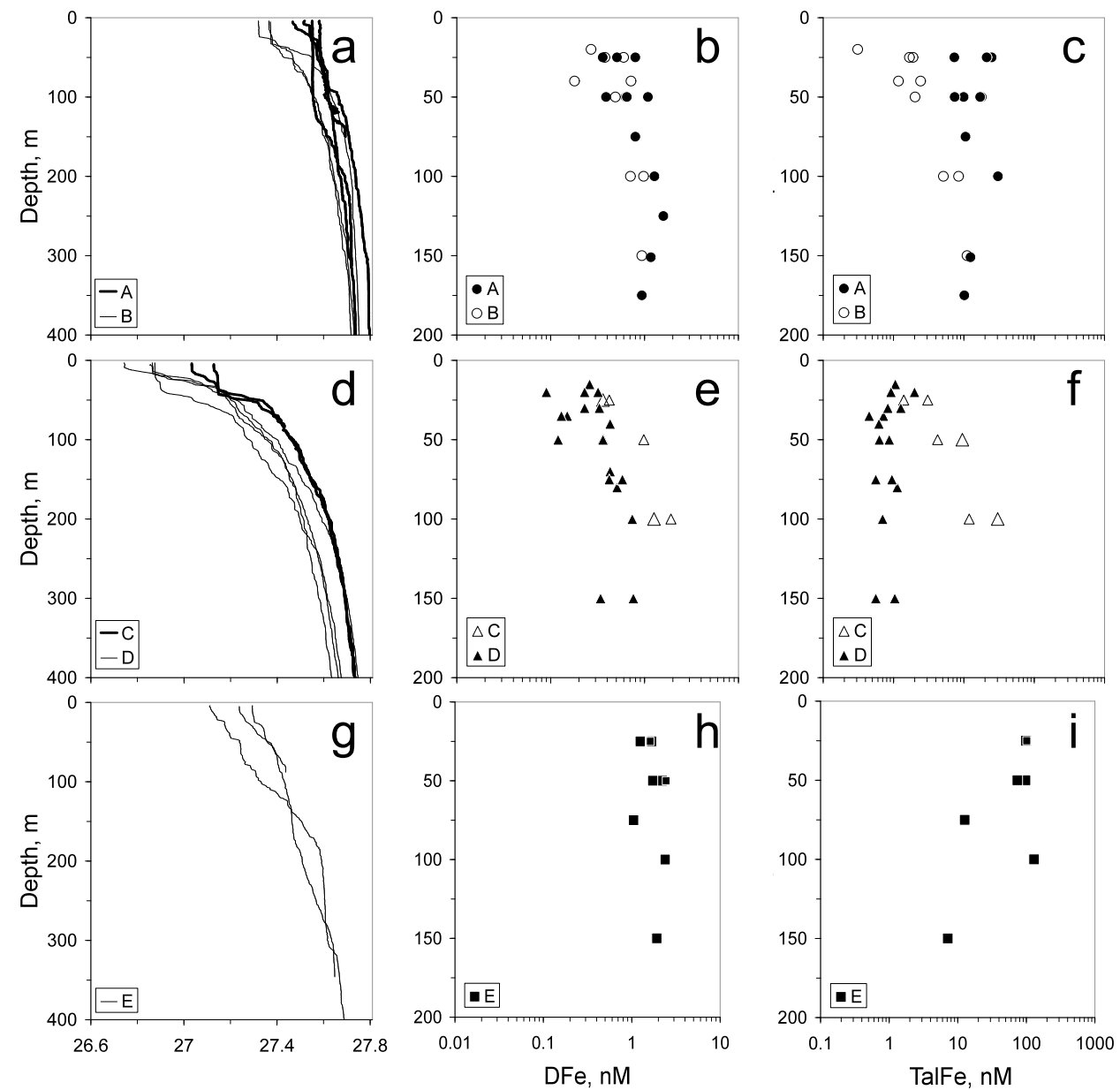

Fig. 4. Water density and Fe concentrations relative to water depth. Profiles show density (sigma-q; a, d, g), dissolved Fe concentrations (b, $\mathbf{e}, \mathbf{h})$, and total acid leachable Fe (c, f, i). Stations in groups A(•) and B (o) are shown in (a), (b), (c); Stations in groups C ( $\triangle$ ) and D ( $\mathbf{\Delta})$ are shown in (d), (e), (f); Stations in groups E ( $\mathbf{\square})$ are shown in (g), (h), (i). The stations within each of these five groups are listed in Table 2. 

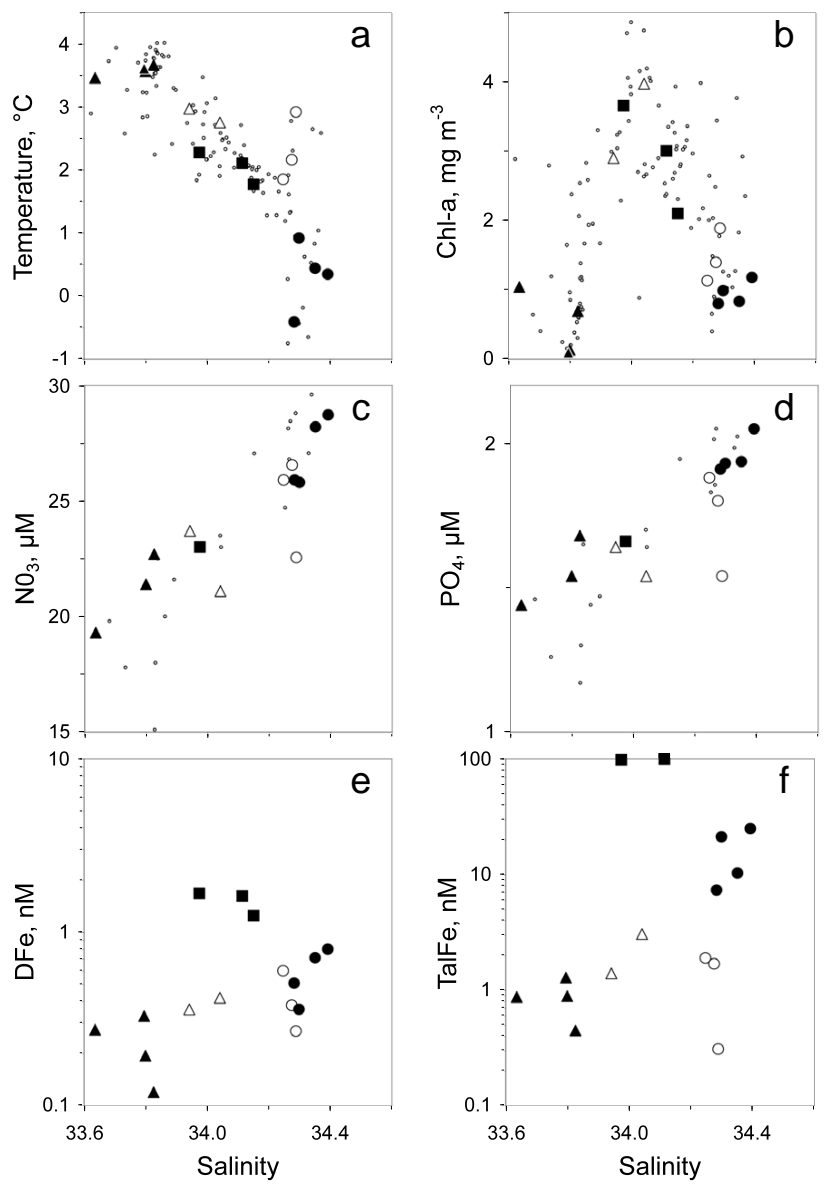

Fig. 5. Mean hydrographic, chemical, and biological values in the upper mixed layer in relation to salinity. (a) temperature; (b) chl- $a$; (c), nitrate; (d) phosphate; (e), dissolved Fe; (f), total acid leachable Fe. group A stations $(\bullet)$, group B stations $(\circ)$, group C stations $(\triangle)$, group D stations $(\boldsymbol{\Delta})$, group E stations $(\mathbf{\square})$. The stations within each of these five groups are listed in Table 2. The small circles (dots) represent data from all the stations where $\mathrm{Fe}$ concentrations were not determined.

\section{Discussion}

\subsection{Fe concentrations in relation to hydrography and surface water flow}

In order to interpret iron concentrations from the 16 stations in relation to the hydrography of the South Shetland Islands, it is useful to understand the general circulation for surface waters in the AMLR survey area. The complexity of surface water flow in this area is illustrated by Lagrangian drifter tracks (Fig. 10a). Bottom topography such as the Shackleton Transverse Ridge and the continental shelf break strongly influence the flow of surface water. The drifters were often concentrated in fast moving jets, such as the one flowing in a northeasterly direction along the shelf break to the south of the South Shetland Islands and the jet flowing in a northwest-
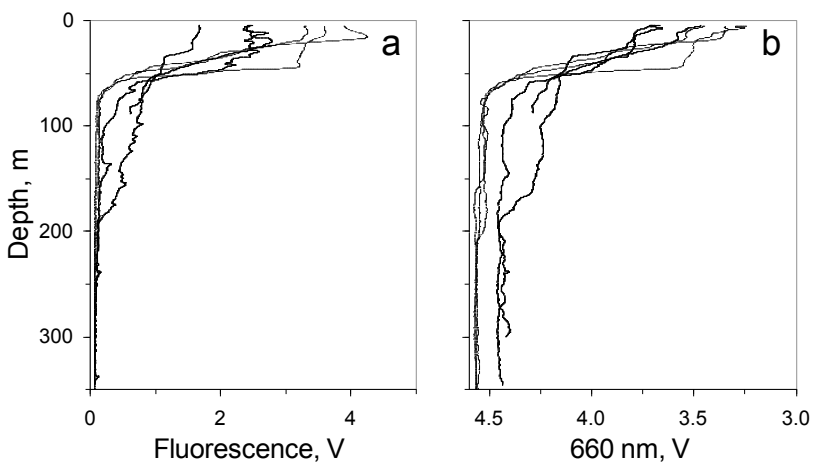

Fig. 6. Evidence of benthic input of $\mathrm{Fe}$ into coastal wasters. Upper water column characteristics at the three outer coastal survey stations (light lines, station \#8 and 9, and one station in between) and at the three stations closest to shore (dark lines, station \#15 and 16 and one station to the east of station \#16). (a) profiles of in situ chl- $a$ fluorescence; (b) profiles of beam attenuation at $660 \mathrm{~nm}$.

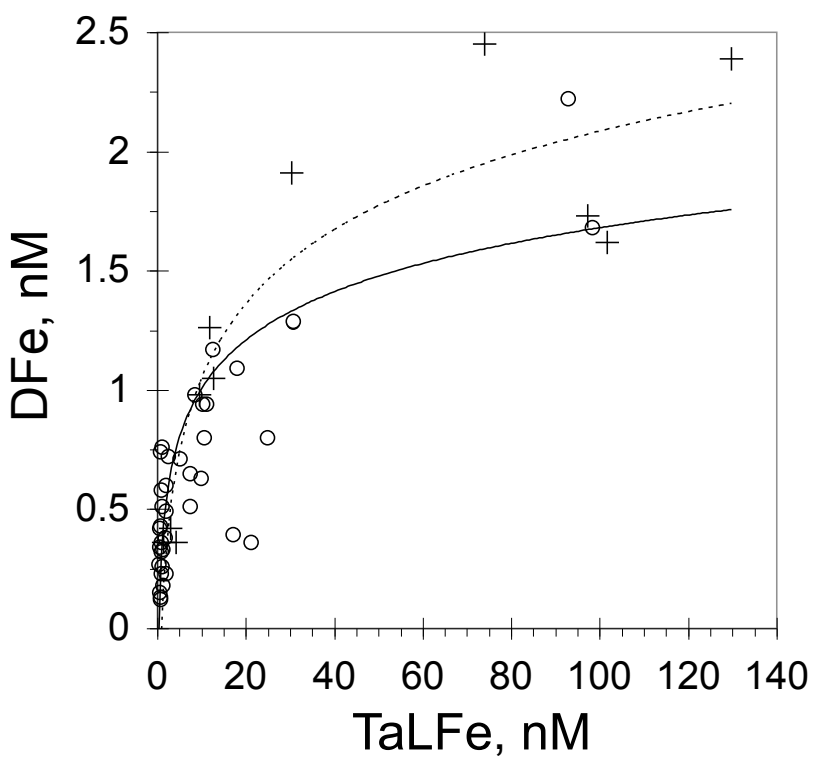

Fig. 7. Relation of dissolved Fe to total acid leachable Fe. The lower, dark regression line utilizes data from all stations. The upper, dashed regression line utilizes data from only the coastal survey stations (+, station \#8-9, 15-16).

erly direction between the Powell Basin and Joinville island. The drifter tracks in Bransfield Strait (black tracks) show eddies to the south of King George Island (the center of the eddy is over deep water of the central basin, and close to the location of station \#7), a smaller one at $\sim 55.5^{\circ} \mathrm{W}$, and a larger one over shallow water close to $54^{\circ} \mathrm{W}$ (the center of the eddy is close to the location of Station \#1). These drifter tracks can be used to generalize surface water flow patterns in our study area (Fig. 10b). It is seen that the surface waters in Bransfield Strait originate both from the shelf regions 


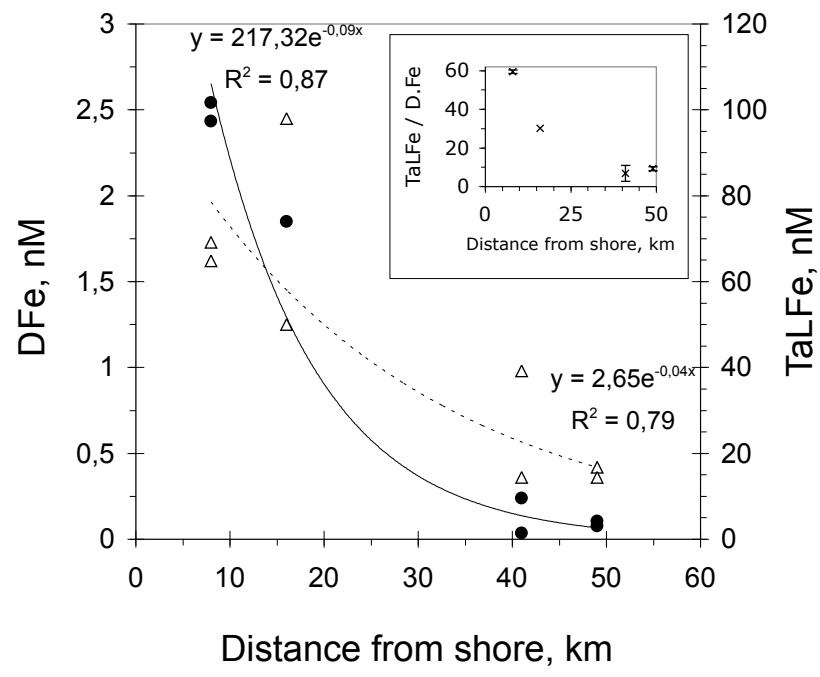

Fig. 8. Concentrations of $\mathrm{Fe}$ used to estimate scale lengths for dissolved and total acid leachable Fe. Exponential regressions were used to fit to data (curved lines) from four coastal stations (\#8-9, $15-16)$ to determine the scale lengths for $\operatorname{DFe}(\triangle$, dashed line) and TaLFe (•, solid line). Equations for each regression are shown. Only surface values $(<50 \mathrm{~m})$ were used in these regressions. The inset shows the variation of TaLFe: DFe ratios with distance from shore.

of the Weddell Sea to the south as well as from the Powell Basin region of the Weddell Sea (von Gyldenfeldt et al., 2002). This outflow from the cyclonic Weddell Sea gyre becomes enriched in sediment-derived Fe during flow over the shallow shelf regions of the Weddell Sea and the Antarctic Peninsula before trifurcating, with part flowing toward the southwest over the northern shelf regions of the Antarctic Peninsula, another part flowing to the northwest in the direction of Elephant island which forms an anti-cyclonic eddy in Bransfield Strait, and the third part flowing north and then northeast. In the southern region of Bransfield Strait the cold, high salinity and Fe-enriched waters from the Weddell Sea mix with the warmer and fresher waters originating from the Drake Passage and the Bellingshausen Sea that then flows to the northeast as described by Zhou et al. (2006).

The Fe concentrations in our study area (Fig. 5e, f) reflect the general water flow patterns (Fig. 10b) when the Fe concentrations in the two major source waters (Drake Passage and Weddell Sea waters) for this area are considered. Drake Passage waters have low DFe concentrations $(\sim 0.16 \mathrm{nM}$; Martin et al., 1990), in contrast to the higher Fe waters of the Weddell Sea (0.24 to $5.6 \mathrm{nM}$; Westerland and Öhman, 1991). Near-shore and shallow stations in the Weddell Sea have much higher $\mathrm{Fe}$ concentrations $(4.5$ to $50 \mathrm{nM})$ as reported by Sañudo-Wilhelmy et al. (2002) and de Baar and de Jong (2001). The surface water flow patterns (Fig. 10b) show that the Fe-rich shelf waters of the Weddell Sea flow into the southern portions of Bransfield Strait where stations \#1-4 are located. With the exception of the three shallow coastal sta- tions (\#14-16) with very high DFe concentrations, our highest DFe concentrations were found at these stations (\#1-4) in the southern Bransfield Strait. As indicated in Fig. 10b, the Fe-rich waters in the southwestern portion of Bransfield Strait mix with low-Fe waters from the Drake Passage as pointed out by Hewes et al. $(2008,2009)$ and then flow in a northeasterly direction to include the sampling area for station \#5-7. Part of this northeasterly flow of water turns to the north around King George Island and then in a southwesterly direction where stations \#8 and 9 are located. The DFe concentrations at these stations (\#5-9) are intermediate between the high Fe concentrations of the Weddell Sea and the low $\mathrm{Fe}$ concentrations in the Drake Passage stations (\#10-13). Our DFe data for the Bransfield Strait and the coastal zones are lower than some of the values cited above. This is probably because of consumption by phytoplankton that had attained exceptionally high biomass during 2006. In the South Shetland Islands area, highest chl- $a$ concentrations occur at salinities 34.0 \pm 1 (see Fig. 5b; Hewes et al., 2008, 2009), with

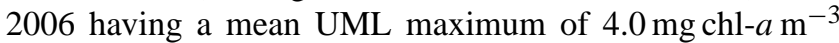
for this salinity range, compared with an 18-year mean of $1.3 \mathrm{mg}$ chl- $a \mathrm{~m}^{-3}$ (see Table 4 in Hewes et al., 2009). In addition, Reiss et al. (2009) show that in the large sub-area of the historical AMLR surveys surrounding Elephant Island, 2006 corresponded (their Fig. 7) with the highest UML chl$a$ as well as lowest silicate and nitrate concentrations of the 18-year AMLR time series.

High TaLFe in the near-shore and shallow zones and relatively high values in Bransfield Strait indicate that much of the TaLFe contained in the particulate fraction originates from coastal sediments. Concentrations of DFe had an upper limit of $\sim 2.5 \mathrm{nM}$ (Fig. 7), despite the increasing concentrations of TaLFe. Upper limits of DFe in seawater are chemically controlled by solubility of iron particles including adsorption/desorption of the DFe onto particles, the complexation of iron with strong and weak organic ligands (Boye et al., 2005; Croot et al., 2004), formation of organic and inorganic iron-colloids $(<0.2 \mu \mathrm{m})$ and involvement of other biological processes (Barbeau et al., 1996; Tovar-Sanchez et al., 2007; Sato et al., 2007; Frew et al., 2006). The concentrations of DFe in our study are well correlated with the concentration of TaLFe (Fig. 7), but when waters are transported off shore much of the TaLFe apparently settles out of the euphotic zone fairly rapidly as compared to the DFe fraction. The ratio of TaLFe/DFe thus varies in relation to distance from shore and depth of the water column. The mean TaLFe/DFe ratio at the near-shore Stations (\#14-16) was $~ 60$ (mean water depth $446 \mathrm{~m}$ ), at Stations (\#1-4) in the southern portions of Bransfield Strait the mean ratio was 21 (mean depth $389 \mathrm{~m}$ ), while at the deep Stations (\#5-13) the mean ratio was 4.3 (mean water depth $2563 \mathrm{~m}$ ). With only TaLFe and DFe values, it is impossible to understand the details of these mechanisms that control the upper limits of the dissolved Fe. However, the logarithmic correlations between TaLFe and DFe $(\mathrm{DFe}=0.31 \cdot \mathrm{Ln}(\mathrm{TaLFe})+0.34$ 

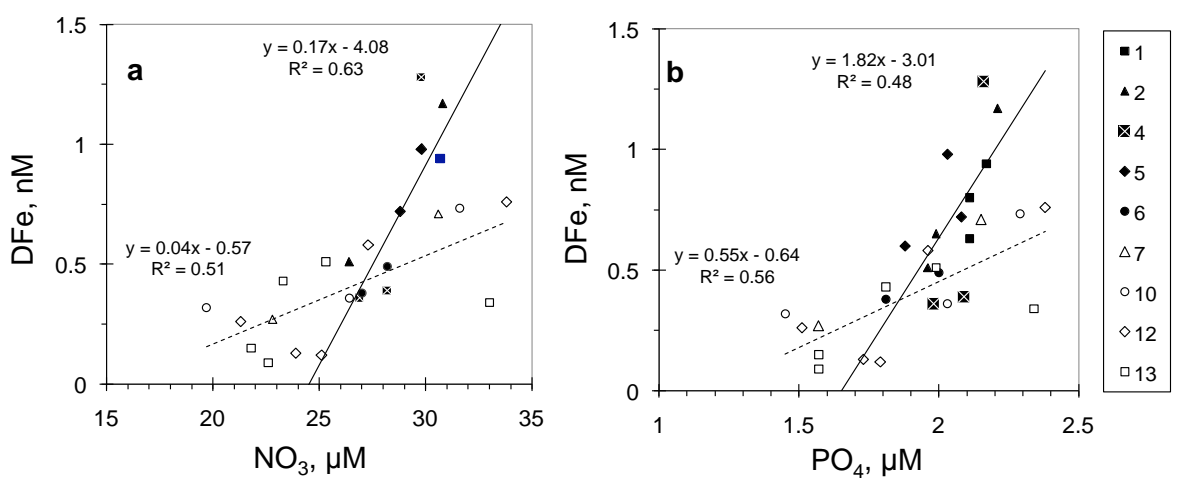

Fig. 9. Relationships between DFe and macronutrients at the nine stations where nutrient concentrations were determined. (a) DFe versus $\mathrm{NO}_{3}$, (b) DFe vs. $\mathrm{PO}_{4}$. Data from Drake Passage stations (\#10, 12, 13) and station 7 are shown as open symbols and data from Bransfield Strait stations (\#1-2, 4-6) are shown with closed symbols. Linear regressions, with equations, are shown for both zones. Station numbers are shown in the column to the right.

$r^{2}=0.78$ for all data, and $\mathrm{DFe}=0.45 \cdot \mathrm{Ln}(\mathrm{TaLFe})+0.01 r^{2}=0.84$ for coastal survey area) in our data imply that when the input of particles is high, loss of DFe due to abiotic particle scavenging might be more effective than the release of dissolved iron from re-suspended particles. In fact, there are some indirect indications of intense near-shore removal processes for dissolved iron (Bucciarelli et al., 2001).

\subsection{Scale lengths of Fe transport}

It is possible that soluble/bioavailable Fe can be leached from suspended TaLFe fractions of particulate $\mathrm{Fe}$ during lateral onshore-offshore transport. The relatively high values of $\mathrm{TaLFe}$ in the surface waters of the northern section of the Bransfield Strait (ranged from 2 to $15 \mathrm{nM}$ ) indicate that transport of particulate iron from both sediment and coastal systems is effective. Frew et al. (2006) showed that lithogenic iron is first transformed into biogenic iron in the euphotic zone, then re-solubilized below the euphotic zone where it is quickly and effectively scavenged by settling particles. The distance that iron can be transported from a coastal system to the open ocean also depends on the current systems in the particular area. Iron transport could be effective in a downstream current from a shallow coastal system to the open ocean (e.g., the northeasterly flow of coastal waters out of Bransfield Strait into the Scotia Sea). In contrast, when the main current flows parallel to the shelf, export from the coastal system into the open ocean would be less effective. Previous studies in our sampling area also demonstrated that lateral transport in transects from the coast to Drake Passage (perpendicular to the main currents) was not as efficient as that in the Bransfield Strait-Elephant Island sections (Dulaiova et al., 2009). To estimate how effective the coastal inputs are for long-range bio-available iron transport, including northward transport by the slower meridional flow (Cassar et al., 2008), we calculated "scale length" of the DFe and TaLFe concentrations from the coastal survey data in two transects which were perpendicular to the coastal currents to the northwest of Livingston Island (see Fig. $1 \mathrm{~b}$ and 10b). As an indicator of the degree of horizontal transport of iron from coast to open ocean, "scale length" (SL) is defined as "the distance over which concentrations drop to $1 / \mathrm{e}(1: 2.72=0.37)$ of the initial Fe concentration" at the shore (Johnson et al., 1997). We estimated SL for DFe $\left(\mathrm{SL}_{\mathrm{DFe}}\right)$ and TaLFe $\left(\mathrm{SL}_{\mathrm{TaLFe}}\right)$ by plotting DFe and TaLFe from coastal survey stations versus distance from shoreline (Fig. 8). Surface data $(<50 \mathrm{~m})$ were fit with exponential regressions, with $\mathrm{SL}_{\mathrm{DFe}}$ and $\mathrm{SL}_{\mathrm{TaLF}}$ found as 25 and $12 \mathrm{~km}$, respectively. These values indicate that neither dissolved nor particulate iron penetrate far into open ocean in the latitudinal/meridional direction when the main current is parallel to the coast. Our estimate of $\mathrm{SL}_{\mathrm{DFe}}(25 \mathrm{~km})$ is identical to the $\mathrm{SL}_{\mathrm{DFe}}$ found by Planquette et al. (2007) and is comparable to the $\mathrm{SL}_{\mathrm{DFe}}(16 \mathrm{~km})$ found by Johnson et al. (1997) for Monterey Bay. However, much higher values for $\mathrm{SL}_{\mathrm{DFe}}$ were estimated for near-shore waters off the Kerguelen Islands $(151 \mathrm{~km}$; Bucciarelli et al., 2001) and near the Galapagos Islands $(103 \mathrm{~km}$; Gordon et al., 1998). These differences were attributed to different water circulation patterns in those coastal systems and the difference between the respective surface areas of the islands (Planquette et al., 2007). Geochemical characteristic of the source area, type of continental shelf and margin, and differences in the biological processes might also play some role.

\subsection{Cellular quotas of iron and carbon, and estimation of iron supply}

Bio-available $\mathrm{Fe}$ input into the Antarctic PeninsulaBransfield Strait region is important for supporting high rates of primary production in the South Shetlands Islands area as well as in the western Scotia Sea (see Fig. 1). It is of interest to obtain some idea of the mean cellular iron quota $(\mathrm{Fe}: \mathrm{C})$ for the phytoplankton community to compare with other regions. Crude estimates of cellular iron quota can be obtained 

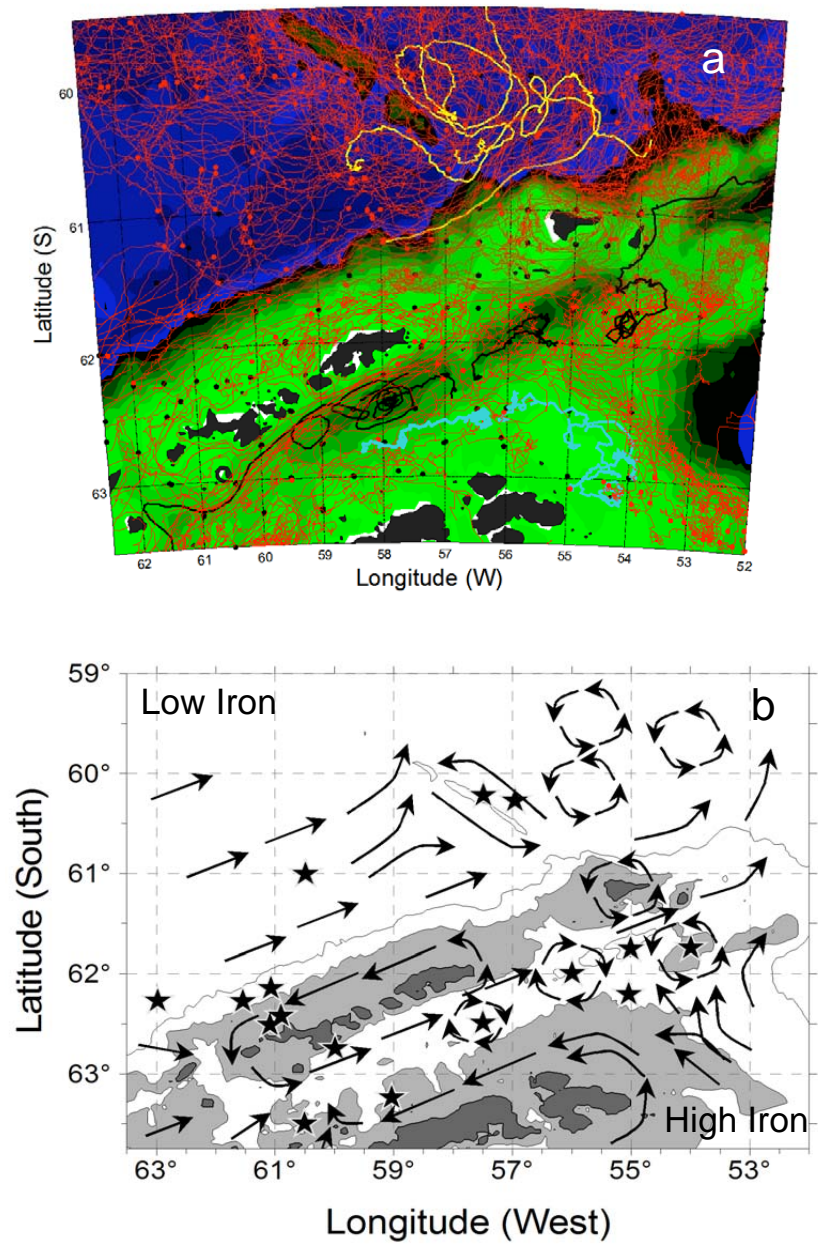

Fig. 10. Location of the 16 stations where Fe concentrations were determined in relation to water flow patterns in the Drake PassageAntarctic Peninsula area. (a), Drifter tracks (in red, yellow, and black) showing the complexity of surface water flow. Green areas indicate increasing depth of the shelf regions, with the darkest green representing $2000 \mathrm{~m}$ depth. The small red and black circles indicate the location where each drifter was deployed. The drifter tracks in black illustrate the presence of eddies in Bransfield Strait. The drifter tracks in yellow show the effect of the Shackleton Transverse Ridge in steering water flow through the deep channel between the Ridge and Elephant Island, and the gyre-like tracks of the drifters to the east of the Ridge and north of Elephant Island. (b) Map of the sampling area showing generalized pattern of surface currents based on drifter track data, hydrographic data, and published water flow patterns. Figure has been modified from Fig. 1 in Hewes et al. (2009), but with more detail regarding water circulation. The darkest areas are islands and the northern tip of the Antarctic Peninsula. The lighter grey areas are bounded by the $500 \mathrm{~m}$ depth contour. The light continuous line is the $2000 \mathrm{~m}$ isobath. The topographical features (just to the west of stations 12 and 13) in the Drake Passage are part of the Shackleton Transverse Ridge, portions of which are $<1000 \mathrm{~m}$ in depth. The stars show the locations of the 16 stations where Fe concentrations were determined. For identification of the land and sea areas refer to Fig. 1. by proxy from Redfield ratios as done by Sunda and Huntsman (1995), who assumed that the slopes of regressions of iron vs. phosphate concentrations with depth provide an indicator of cellular Fe:P ratios. Similarly we assumed that concentrations in the pycnocline represented winter surface values, and derived drawdown ratios for $\mathrm{Fe}$ and $\mathrm{NO}_{3}$, such that:

$$
\begin{aligned}
\Delta \mathrm{Fe} / \Delta \mathrm{NO}_{3}= & \left(\mathrm{DFe}_{\text {pycnocline }}-\mathrm{DFe}_{\mathrm{UML}}\right) / \\
& \left(\mathrm{NO}_{3} \text { pycnocline }-\mathrm{NO}_{3 \mathrm{UML}}\right),
\end{aligned}
$$

where $\mathrm{DFe}_{\text {pycnocline, }} \mathrm{NO}_{3 \text { pycnocline }}$ are mean pycnocline values, and $\mathrm{DFe}_{\mathrm{UML}}$ and $\mathrm{NO}_{3 \mathrm{UML}}$ are mean concentrations for the UML. For the pycnocline, mean DFe, and $\mathrm{NO}_{3}$ concentrations were $\sim 1 \mathrm{nM}$ and $30.5 \mu \mathrm{M}$ respectively, and concentrations for the UML of $\mathrm{DFe}$ and $\mathrm{NO}_{3}$ were $\sim 0.5 \mathrm{nM}$ and $\sim 27 \mu \mathrm{M}$, respectively. For Bransfield Strait, $\Delta \mathrm{Fe}: \Delta \mathrm{NO}_{3}=0.17 \mathrm{nmol}: \mu \mathrm{mol}$ being the same as the slope of the regression between $\mathrm{DFe}$ and $\mathrm{NO}_{3}$ for all data (Fig. 9a). Similarly, $\Delta \mathrm{Fe}: \Delta \mathrm{NO}_{3}=0.05 \mathrm{nmol}: \mu \mathrm{mol}$ for Drake Passage, also close to the slope of 0.04 from regression between DFe and $\mathrm{NO}_{3}$ for all data (Fig. 9a). Redfield ratios provide $\mathrm{Fe}: \mathrm{C}=6 \pm 3 \mu \mathrm{mol}: \mathrm{mol}$ in the Drake Passage water and 26 $\pm 7 \mu \mathrm{mol}: \mathrm{mol}$ in Bransfield Strait when C:N=6.6 mol:mol. Similarly, from the slope of DFe vs. P (Fig. 9b) we estimate $\mathrm{Fe}: \mathrm{C}=5.2 \pm 3$ and 17.2 $\pm 4 \mu \mathrm{mol}: \mathrm{mol}$ in the Drake Passage and Bransfield Strait, respectively, when C:P=106 mol:mol.

For Bransfield Strait average $\mathrm{P}$ concentrations were $\sim 2.1 \mu \mathrm{M}$ and $\sim 1.9 \mu \mathrm{M}$ for the pycnocline and the UML, respectively. For the Drake Passage average $\mathrm{P}$ concentrations were $\sim 1.9 \mu \mathrm{M}$ and $\sim 1.6 \mu \mathrm{M}$ for the pycnocline and the UML, respectively. By using similar equation as Eq. (1) for $\mathrm{P}, \Delta \mathrm{Fe}: \Delta \mathrm{P}$ are estimated to be $2.5 \pm 0.7$ and $0.6 \pm 0.2 \mathrm{nmol}: \mu \mathrm{mol}$, for Bransfield Strait and the Drake Passage, respectively. Redfield ratios $(\mathrm{C}: \mathrm{P}=106 \mathrm{~mol}: \mathrm{mol})$ provide $\mathrm{Fe}: \mathrm{C}=6 \pm 3 \mu \mathrm{mol}: \mathrm{mol}$ in the Drake Passage water and $24 \pm 7 \mu \mathrm{mol}: \mathrm{mol}$ in Bransfield Strait when which are also close to $\mathrm{Fe}: \mathrm{C}$ estimations based on the slope of the regression between DFe and P (Fig. 9b). Such estimates are very rough, not taking into account different flow and dilution rates of various isopycnals that upwell and downwell in the area (Hewes et al., 2008) and would lead to different residence times of $\mathrm{Fe}, \mathrm{P}$, and $\mathrm{N}$ in both the UML and pycnocline, as well as, different regeneration rates of $\mathrm{Fe}$ and macronutrient through grazing processes (Frew et al., 2006). However, such values do compare with those obtained from The Southern Ocean Iron Experiment (SOFeX) for Fe:C of $\sim 10 \mu \mathrm{mol}$ :mol under Fe-stress and $\sim 40 \mu \mathrm{mol}$ :mol with Feenrichment (Twining et al., 2004). Variation in published cellular Fe:C ratio is large depending on the method used to obtain it and locations (Boyd et al., 2007 and reference therein). In the Southern Ocean, the published $\mathrm{Fe}: \mathrm{C}$ ratio varies about $\sim 5$ to $\sim 50 \mu \mathrm{mol}$ :mol and can increase $\geq 100 \mu \mathrm{mol}$ :mol by artificial Fe enrichment experiments (Boyd et al., 2007). 
The iron demand of phytoplankton can be estimated from $\mathrm{Fe}: \mathrm{C}$ and primary productivity. Total primary production can be estimated (Holm-Hansen and Mitchell, 1991) as:

$\mathrm{mg}$ carbon fixed $\mathrm{m}^{-2} \mathrm{~d}^{-1}=0.32 \cdot\left(\mathrm{mg} \mathrm{chl}-a \mathrm{~m}^{-2}\right)$

$$
\cdot\left(\text { Einstein } \mathrm{m}^{-2} \text { day }^{-1}\right)
$$

with chl- $a$ integrated through the euphotic zone. Mean incident PAR during the 2006 survey was obtained from direct measurements of cosine PAR taken aboard ship, with daylight (08:00-24:00 GMT) hours only considered (38.1 Einstein $\left.\mathrm{m}^{-2} \mathrm{~d}^{-1}\right)$, and euphotic zone estimated directly from daytime stations. Mean rates of daily primary production for Drake Passage and Bransfield Strait were estimated at $278 \mathrm{mg} \mathrm{C} \mathrm{m}^{-2} \mathrm{~d}^{-1}$ (with mean euphotic depth of $54 \mathrm{~m}$ ) and $600 \mathrm{mg} \mathrm{C} \mathrm{m}^{-2} \mathrm{~d}^{-1}$ (mean euphotic depth of $35 \mathrm{~m}$ ), respectively. Despite the fact that this estimate of primary production may have some degree of uncertainty, it is still useful to estimate the range of the iron demand in the region. Total primary productivity was factored by 0.15 (Drake Passage) and 0.22 (Bransfield Strait) to obtain amounts of "new" primary production (factor values based on rates of nutrient regeneration where the f-values averaged $\sim 0.15$ in Drake passage stations and 0.22 in Bransfield straits as reported by Rönner et al. (1983) and Koike et al. (1986). Hence, mean daily rates of new primary production at the Drake Passage and Bransfield stations would be 42 and $132 \mathrm{mg} \mathrm{C} \mathrm{m}^{-2} \mathrm{~d}^{-1}$ (3.5 and $\left.11 \mathrm{mmol} \mathrm{C} \mathrm{m}^{-2} \mathrm{~d}^{-1}\right)$, respectively.

The integrated $\mathrm{Fe}$ demand can be calculated by using Eq. (2)

$\mathrm{Fe}_{\text {demand }}=$ newPP $\cdot(\mathrm{Fe}: \mathrm{C})_{\text {cellular }}$

and cellular Fe:C estimated to be $\sim 6$ and $\sim 26 \mu \mathrm{mol} \mathrm{mol}^{-1}$ for Drake passage and Bransfield Strait zones, respectively.

For the euphotic zone in Drake Passage and Bransfield Strait stations, the rough estimate of the integrated $\mathrm{Fe}$ demand is $\sim 21$ and $\sim 286 \mathrm{nmol} \mathrm{m}^{-2} \mathrm{~d}^{-1}$, respectively. The Fe demand in Bransfield Strait is apparently $>10$ time higher than that of Drake Passage. Calculated lateral DFe supply based on $\mathrm{Fe} /{ }^{228} \mathrm{Ra}$ ratios in the Elephant island zone (i.e. the northeast region of Bransfield Strait) was around $1800 \mathrm{nmol} \mathrm{m}^{-2} \mathrm{~d}^{-1}$ (Dulaliova et al., 2009), This value is beyond the estimated value of the integrated Fe demand of $\sim 286 \mathrm{nmol} \mathrm{m}^{-2} \mathrm{~d}^{-1}$ in Bransfield Strait. This estimation suggests that lateral supply of DFe should be more than enough to support the observed primary productivity in the northeast region of Bransfield Strait.

\subsection{Sources of Fe to support high phytoplankton biomass in the Scotia Sea}

Satellite imagery of chl- $a$ concentrations during austral summer show that both Drake Passage and Weddell Sea waters have very low chl- $a$ concentrations, in contrast to the high chl- $a$ levels over the northern and southern continental shelf regions of the South Shetland Islands which includes Elephant Island (Fig. 1). Phytoplankton biomass (and hence chl- $a$ levels) are known to be Fe-limited in Drake Passage waters (Martin et al., 1990; Helbling et al., 1991; Hopkinson et al., 2007). In contrast, deep surface mixing probably limits phytoplankton biomass in high saline Weddell waters due to light limitation in the deep UML (Hewes et al., 2008; see Fig. 5b). High chl- $a$ concentrations $\left(>1.0 \mathrm{mg} \mathrm{m}^{-3}\right)$ around the South Shetland Islands continues as a band toward the northeast over the deep waters of the central portion of the Scotia Sea (see Fig. 1a) and stretches to $\sim 40^{\circ} \mathrm{W}$, just to the southwest of South Georgia. Much of this rich chl- $a$ region in the Scotia Sea lies in ACC waters to the north of the Southern Extent of Antarctic Circumpolar Current sequence waters (SEACC), with the rest of it lying in the mixing zone between the SEACC and the Northern Extent of Weddell Sea sequence waters as described by Whitworth et al. (1994).

Since no Fe data are available for this region of the Scotia Sea, the high phytoplankton biomass in the central portion of the Scotia Sea can only be speculated as the result of natural $\mathrm{Fe}$ fertilization from the peninsular area. The major sources of waters in the Scotia Sea are (i) ACC waters flowing through Drake Passage, (ii) waters from Bransfield Strait and the shelf regions of the SSI, and (iii) Weddell Sea waters flowing directly into the Scotia Sea. Surface waters of the ACC just to the west of Drake Passage have low concentrations of both DFe $(<0.2 \mathrm{nM})$ and TaLFe $(<0.50 \mathrm{nM})$ as reported by de Baar and de Jong (2001). These values are slightly lower than we found in the ACC waters (see Fig. 5e, f), and are concentrations not capable of supporting the high chl- $a$ concentrations (Martin et al., 1990; Helbling et al., 1991; Hopkinson et al., 2007) such as observed for the Scotia Sea. In contrast to ACC waters, the waters of Bransfield Strait and the shelf regions of the SSI (Fig. 5; SañudoWilhelmy et al., 2002; Hewes et al., 2008) have much higher concentrations of both DFe and TaLFe.

The concept that natural phytoplankton assemblages are Fe-limited in ACC waters but not in Bransfield Strait waters is supported by the Fe-addition experiments of Helbling et al. (1991) and Hopkinson et al. (2007). The high chl- $a$ regions in Fig. 1a suggest that the northeasterly flow of Feenriched waters from the Peninsular region may be responsible for the high chl- $a$ concentrations in the central portion of the Scotia Sea. Although the southern regions of the Scotia sea close to the Scotia Ridge are enriched in $\mathrm{Fe}$ from sediment-derived Fe from the South Scotia Ridge (de Baar et al., 1990), as well as from Fe-enriched Weddell Sea waters flowing north through the deep Philip Passage to the west of the South Orkney Islands (Foster and Middleton, 1984), concentrations of chl- $a$ indicate that such Fe-enriched waters do not extend very far north into the central Scotia Sea (Biggs et al., 1982). Water from the Weddell Sea also flows north in the deep passages of the Scotia Ridge to the east of the South Orkney Islands (Heywood et al., 2004), but this abyssal flow 
of Weddell Sea water into the Scotia Sea apparently has no surface expression.

Our results with the circulation patterns provide evidence for natural iron enrichments in the region and allow us to suggest that northeastward horizontal advection from the South Shetland Islands-Antarctic Peninsula coastal system carries necessary iron to support the relatively high rates of primary production known from the central regions of the Scotia Sea. In order to create a complete iron balance, future studies must consider testing and comparison of other possible sources of Fe enrichment in surface waters of the Scotia Sea, which include (i) upwelling phenomena associated with the various frontal systems in the Scotia Sea (Löscher et al., 1997; Holm-Hansen et al., 2004), (ii) eddy formation which involves both downwelling and upwelling processes (Kahru et al., 2007), (iii) isopycnal mixing south of the Polar Front (Pollard et al., 2006), (iv) upwelling of isopycnals over shallow topographical features (Sullivan et al., 1993; HolmHansen et al., 2005), and (iv) aeolian input (Gao et al., 2003).

Acknowledgements. We wish to thank the officers and crew of $R / V$ Yuzhmorgeologiya for their invaluable help during the course of this field study, and the NOAA US AMLR Program team that made this study possible with logistics support and help in collecting samples. The authors are very grateful to Svein Kristiansen from University of Troms $\varnothing$, for lending his GO-FLO bottles and S. Lierhagen for his contribution performing the HR-ICP-MS analysis. This work was supported by the Norwegian Polar Institute (grant 3557-103-E. Sakshaug) and the US AMLR Program, administered by the Antarctic Ecosystem Research Division at NOAA's Southwest Fisheries Research Center, La Jolla, California, under grant NA17RJ1231 (O. Holm-Hansen). Views contained herein are those of the authors and do not reflect those of NOAA.

Edited by: D. Turner

\section{References}

Atlas, E. L., Gordon, L. I., Hager S. W., and Park, P. K.: A Practical Manual for Use of the Technicon Autoanalyzer in Seawater Nutrient Analyses (Revised). Tech. Report 215, Department of Oceanography, Oregon State University, Corvallis, OR 97331, 1971.

Baffi, F. and Cardinale, A.: Improvements in use of Chelex-100 resin for determination of copper, cadmium and iron in seawater, Int. J. Anal. Chem., 41, 15-20, 1990.

Barbeau, K., Moffett, J. W., Caron, D. A., Croot, P. L., and Erdner D. L.: Role of protozoan grazing in relieving iron limitation of phytoplankton, Nature, 380, 61-64, 1996.

Biggs, D. C., Johnson, M. A., Bidigare, R. R., Guffy, J. D., and Holm-Hansen, O.: Shipboard autoanalyzer studies of nutrient chemistry, 0-200 m, in the eastern Scotia Sea during FIBEX (January-March, 1981). Texas A\&M University, Department Oceanography Technical Reports, 88-11-T, 1982.

Blain, S. Queguiner, B., Armand, L., and 44 others.: Effect of natural iron fertilization on carbon sequestration in the Southern Ocean, Nature, 446, 1070-1074, doi:10.1038/nature05700, 2007.
Blain, S., Sarthou, G., and Laan, P.: Distribution of dissolved iron during the natural iron fertilization experiment KEOPS (Kerguelen Plateau, Southern Ocean), Deep Sea Res. II, 55, 594-605, doi:10.1016/j.dsr2.2007.12.028, 2008.

Boye, M., Nishioka, J., Croot, P. L., Laan, P., Timmermans, K. R., and de Baar, H. J. W.: Major deviations of iron complexation during 22 days of a mesoscale iron enrichment in the open Southern Ocean, Mar. Chem., 96, 257-271, 2005.

Boyd, P. W. and Law, C. S.: The Southern Ocean Iron RElease Experiment (SOIREE) - introduction and summary, Deep-Sea Res. II, 48, 2425-2438, 2001.

Boyd, P. W., Jickells, T., Law, C. S., Blain, S., Boyle, E. A., Buesseler, K. O., Coale, K. H., Cullen, J. J., de Baar, H. J. W., Follows, M., Harvey, M., Lancelot, C., Levasseur, M., Owens, N. P. J., Pollard, R., Rivkin, R. B., Sarmiento, J., Schoemann, V., Smetacek, V., Takeda, S., Tsuda, A., Turner, S., and Watson, A. J.: Mesoscale iron enrichment experiments 1993-2005: synthesis and future directions, Science, 315, 612-617, 2007.

Bruland K. W. and Rue E. L.: Iron: analytical methods for the determination of concentrations and speciation, in: The Biogeochemistry of Iron in Seawater, Hunter, K. A. and Turner, D. R., IUPAC Book Series on Analytical and Physical Chemistry of Environmental Systems, John Wiley and sons, Chichester, UK, 255-289, 2001.

Bruland, K. W., Rue, E. L. Smith, G. J., and DiTullio, G. R.: Iron, macronutrients and diatom blooms in the Peru upwelling regime: brown and blue waters of Peru, Mar. Chem., 93, 81-103, 2005.

Bucciarelli, E., Blain, S., and Tréguer, P.: Iron and manganese in the wake of the Kerguelen Islands (Southern Ocean), Mar. Chem., 73, 21-36, 2001.

Cassar, N., Bender, M. L., Barnett, B. A., Fan, S., Moxim, W. J., Levy II, H., and Tilbrook, B.: Response to Comment on "The Southern Ocean Biological Response to Aeolian Iron Deposition", Science, 319(5860), 159b, 2008.

Croot, P. L. Andersson, K., Öztürk, M., and Turner, D. T.: The distribution and speciation of iron along $6^{\circ} \mathrm{E}$ in the Southern Ocean, Deep-Sea Res. II, 51, 2857-2879, 2004.

de Baar, H. J. W., de Jong, J. T. M., Bakker, D. C. E., Löscher, B. M., Veth, C., Bathmann, U., and Smetacek, V.: Importance of iron for plankton blooms and carbon dioxide drawdown in the Southern Ocean, Nature, 373, 412-415, 1995.

de Baar, H. J. W., Buma, A. G. J., Nolting, R. F., Cadee, G. C., Jacques, G., and Treguer, P. J.: On iron limitation of the Southern Ocean: experimental observations in the Weddell and Scotia Seas, Mar. Ecol. Prog. Ser., 65, 105-122, 1990.

de Baar, H. J. W. and de Jong J. T. M.: Distributions, Sources and Sinks of Iron in Seawater, in: The Biogeochemistry of Iron in Seawater, edited by: Hunter, K. A. and Turner, D. R., IUPAC Book Series on Analytical and Physical Chemistry of Environmental Systems, John Wiley and sons, Chichester, UK, 123-254, 2001.

Dulaiova, H., Ardelan, M. V., Henderson, P. B., and Charette, M. A.: Shelf-derived iron inputs drive biological productivity in the Scotia Sea, Global Biogeochem. Cy., 23, GB4014, doi:10.1029/2008GB003406, 2009.

Foster, T. D. and Middleton, J. H.: The oceanographic structure of the eastern Scotia Sea - I. Physical oceanography, Deep-Sea Res., 31, 529-550, 1984.

Frew, R. D. Hutchins, D. A., Nodder, S., Sanudo-Wilhelmy, S., 
Tovar-Sanchez, A., Leblanc, K., Hare, C. E., and Boyd, P. W.: Particulate iron dynamics during FeCycle in subantarctic waters southeast of New Zealand Global Biogeochem. Cy., 20, GB1S93, doi:10.1029/2005GB002558, 2006.

Gao, Y., Fan, S. M., and Sarmiento, J.: Aeolian iron input to the ocean through precipitation scavenging: a modeling perspective and its implication for the natural iron fertilization of the ocean, J. Geophys. Res., 108(D7), 4221-4232, 2003.

Gordon, R. M., Johnson, K. S., and Coale, K. H.: The behavior of iron and other trace elements during the IronEx-I and PlumEx experiments in the Equatorial Pacific, Deep-Sea Res. II, 45, 9951041, 1998.

Grotti, M. Soggia, F., Abelmoschi, M., Rivaro, P., Magi, E., and Frache, R.: Temporal distribution of trace metals in Antarctic coastal waters, Mar. Chem., 76, 189-209, 2001.

Hansen, D. V. and Poulain, P.-M.: Quality control and interpolation of WOCE/TOGA drifter data, J. Atmos. Ocean. Tech., 13, 900909, 1996.

Helbling, E. W., Villafane, V., and Holm-Hansen, O.: Effect of Fe on Productivity and Size Distribution of Antarctic Phytoplankton, Limnol. Oceanogr., 36, 1879-1885, 1991.

Hewes, C. D., Reiss, C. S., Kahru, M., Mitchell, B. G., and HolmHansen, O.: Control of phytoplankton biomass by dilution and mixed layer depth in the western Weddell-Scotia Confluence, Mar. Ecol. Prog. Ser., 366, 15-29, 2008.

Hewes, C. D., Reiss, C. S., and Holm-Hansen, O.: A quantitative analysis of sources for summertime phytoplankton variability over 18 years in the South Shetland Islands (Antarctica) region, Deep-Sea Res. I, 56, 1230-1241, doi:10.1016/j.dsr.2009.01.010, 2009.

Heywood, K. J., Naveira-Garabato, A. C., Stevens, D. P., and Muench, R. D.: On the fate of the Antarctic slope front and the origin of the Weddell Front, J. Geophys. Res., 109, C06021, doi:10.1029/2003JC002053, 2004.

Hofmann, E. E., Klinck, J. M., Lascara, C. M., and Smith, D. A.: Water mass distribution and circulation west of the Antarctic Peninsula and including Bransfield Strait, in: Foundations for Ecological Research West of the Antarctic Peninsula, edited by: Ross, R. M., Hofmann, E. E., and Quetin, L. B., American Geophysical Union, Washington, DC, 61-80, 1996.

Hofmann, E. E., Klinck, J. M., Locarnini, R. A., Fach, B., and Murphy, E.: Krill transport in the Scotia Sea and environs, Antarctic Sci., 10, 406-415, 1998.

Holm-Hansen, O. and Riemann, B.: Chlorophyll a determination: Improvements in methodology, Oikos, 30, 438-447, 1978.

Holm-Hansen, O. and Mitchell, B. G.: Spatial and temporal distribution of phytoplankton and primary production in the western Bransfield Strait region, Deep-Sea Res., 38, 961-980, 1991.

Holm-Hansen, O. and Hewes, C. D.: Deep chlorophyll- $a$ maxima (DCMs) in Antarctic waters: I, Relationships between DCMs and the physical, chemical, and optical conditions in the upper water column, Polar Biol., 27, 699-710, 2004.

Holm-Hansen, O., Kahru, M., Hewes, C. D., Kawaguchi, S., Kameda, T., Sushin, V. A., Krasovski, I., Priddle, J., Korb, R., Hewitt, R. P., and Mitchell, B. G.: Temporal and spatial distribution of chlorophyll- $a$ in surface waters of the Scotia Sea as determined by both shipboard measurements and satellite data, Deep-Sea Res. II, 51, 1323-1331, 2004.

Holm-Hansen, O., Kahru, M., and Hewes, C. D.: Deep chlorophyll- $a$ maxima (DCMs) in pelagic Antarctic waters. II. Relation to bathymetric features and dissolved iron concentrations, Mar. Ecol. Prog. Ser., 297, 71-81, 2005

Hopkinson, B. M., Mitchell, B. G., Reynolds, R. A., Wang, H., Selph, K. E., Measures, C. I., Hewes, C. D., Holm-Hansen, O., and Barbeau, K. A.: Iron limitation across chlorophyll gradients in the southern Drake Passage: phytoplankton responses to iron addition and photosynthetic indicators of iron stress, Limnol. Oceanogr., 52, 2540-2554, 2007.

Hoppema, M. H., de Baar, H.J.W., Fahrbach, E., and Hellmer, H. H.: Substantial advective iron loss diminishes phytoplankton production in the Antarctic Zone, Global Biogeochem. Cy., 17, 1025, doi:10.1029/2002GB001957, 2003.

Jeffrey, S. W. and Humphrey, G. F.: New spectrophotometric equations for determining chlorophylls a, b, c1 and c2 in higher plants, algae and natural phytoplankton, Biochem. Physiol. Pflanzen, 167, 191-194, 1975.

Johnson, K. S., Gordon, R. M., and Coale, K. H.: What controls dissolved iron in the world ocean?, Mar. Chem., 57, 137-161, 1997.

Kahru, M., Mitchell, B. G., Gille, S. T., Hewes, C. D., and Holm-Hansen, O.: Eddies enhance biological production in the Weddell-Scotia Confluence of the Southern Ocean, Geophys. Res. Lett., 34, L14603, doi:10.1029/2007GL030430, 2007.

Koike, I., Holm-Hansen, O., and Biggs, D. C.: Inorganic nitrogen metabolism by Antarctic phytoplankton with special reference to ammonium cycling, Mar. Ecol. Prog. Ser., 30, 105-116,1986.

Korb, R. E., Whitehouse, M. J., Atkinson, A., and Thorpe, S. E.: Magnitude and maintenance of the phytoplankton bloom at South Georgia: a naturally iron replete environment, Mar. Ecol. Prog. Ser., 368, 75-91, doi:10.3354/meps07525, 2008.

Löscher, B. M., de Baar, H. J. W., de Jong, J. T. M., Veth, C., and Dehairs, F.: The distribution of Fe in the Antarctic Circumpolar Current, Deep-Sea Res. II, 44, 143-187, 1997.

Martin, J. H., Gordon, R. M., and Fitzwater, S. E.: Iron in Antarctic waters, Nature, 345, 156-158, 1990.

Öztürk, M.: Trends of trace metals ( $\mathrm{Mn}, \mathrm{Fe}, \mathrm{Co}, \mathrm{Cu}, \mathrm{Zn}, \mathrm{Cd}$ and $\mathrm{Pb}$ ) distributions at the oxic-anoxic interface and in sulfidic water of Drammensfjord, Mar. Chem., 48, 329-342, 1995.

Öztürk, M., Steinnes E., and Sakshaug, E.: Iron speciation in the Trondheim Fjord from the perspective of iron limitation for phytoplankton, Estuar. Coast. Sci., 55, 197-212, 2002.

Öztürk, M., Croot, P., Bertilsson, S., Abrahamsson, K., Karlson B., Davis, R. Fransson, A., and Sakshaug, E.: Iron enrichment and photoreduction of iron under PAR and UV in the presence of hydrocarboxylic acid: Implications for phytoplankton growth in the Southern Ocean, Deep-Sea Res. II, 51, 2841-2856, 2004.

Planquette, H. F., Statham, P., Fones, G.R., Charette, M. A., Moore, C. M., Salter, I., Nédélec, F. H., Taylor, S. L., French, M., Baker, A. R., Mahowald, N., and Jickells, T. D.: Dissolved iron in the vicinity of the Crozet Islands, Southern Ocean, Deep-Sea Res. II, 54, 1999-2019, 2007.

Pollard, R., Treguer, P., and Read, J.: Quantifying nutrient supply to the Southern Ocean. Journ. Geophysical Res., 111, CO5011, doi:10.1029/2005JCO03076, 2006.

Pollard, R. T, Sanders, R., Lucas, M., and Statham, P.: The Crozet Natural Iron Bloom and Export Experiment (CROZEX), DeepSea Res. II, 45, 1905-1914, 2007.

Reiss, C. S., Hewes, C. D., and Holm-Hansen, O.: Influ- 
ence of atmospheric teleconnections and Upper Circumpolar Deep Water (UCDW) on phytoplankton biomass around Elephant Island, Antarctica, Mar. Ecol. Prog. Ser., 377, 51-62, doi:10.3354/meps07840, 2009.

Rönner, U., Sörensson, F., and Holm-Hansen, O.: Nitrogen assimilation by phytoplankton in the Scotia Sea, Polar Biol., 2, 137147, 1983.

Sato, M. Takeda, S., and Furuya, K.: Iron regeneration and organic iron(III)-binding ligand production during in situ zooplankton grazing experiment, Mar. Chem., 106, 471-488, 2007.

Sañudo-Wilhelmy, S. A. Olsen, K. A., Scelfo, J. M., Foster T. D., and. Flegal, A. R.: Trace metal distributions off the Antarctic Peninsula in the Weddell Sea, Mar. Chem., 77, 157-170, 2002.

Sullivan, C. W., Arrigo, K. R., McClain, C. R., Comiso, J. C., and Firestone, J.: Distributions of phytoplankton blooms in the Southern Ocean, Science, 262, 1832-1837, 1993.

Sunda, W. G. and Huntsman, S. A.: Iron uptake and growth limitation in oceanic and coastal phytoplankton, Mar. Chem., 50, 189-206, 1995.
Tovar-Sanchez, A., Duarte, C. M., Hernández-León, S., and Sañudo-Wilhelmy, S. A.: Krill as a central node for iron cycling in the Southern Ocean, Geophys. Res. Lett., 34, L11601, doi:10.1029/2006GL029096007, 2007.

Twining, B. S., Baines, S. B., Fisher N. S., and Landry, M. R.: Cellular iron contents of plankton during the Southern Ocean Iron Experiment (SOFeX), Deep-Sea Res., 51, 1827-1850, 2004.

von Gyldenfeldt, A.-B., Fahrbach, E., Garcia, M. A., and Schroder, M.: Flow variability at the tip of the Antarctic Peninsula, DeepSea Res. II, 49, 4743-4766, 2002.

Westerland, S. and Öhman, P.: Iron in the water column of the Weddell Sea, Mar. Chem., 35, 199-217, 1991.

Whitworth III, T., Nowlin Jr., W. D., Orsi, A. H., Locarnini, R. A., and Smith, S. G.: Weddell Sea Shelf Water in the Bransfield Strait and Weddell-Scotia Confluence, Deep-Sea Res., 41, 629641, 1994.

Zhou, M., Niiler, P., Zhu, Y., and Dorland, R.: The Western Boundary Current in the Bransfield Strait, Antarctica, Deep-Sea Res. I, 53, 1244-1252, 2006. 